\title{
Foreign Direct Investment and Economic Growth: Evidence from Bangladesh Economy
}

\author{
Moshfequl Islam Rajib, \\ Redwanur Rahman, \\ School of Economics and Management, \\ Nanjing University of Science and Technology, Nanjing, P.R. China
}

Doi:10.19044/esj.2020.v16n10p38 ～URL:http://dx.doi.org/10.19044/esj.2020.v16n10p38

\begin{abstract}
Among various stimulus for growth in economy, Foreign Direct Investment (FDI) is being considered as a significant one even though there are lot of studies that shows otherwise. The relation of FDI and economic growth is been studied vigorously, but there is hardly any study in-depth about Bangladesh which can give us a rich insight into economic growth and bring out other factors to the picture of economic growth. To do that, this study explores the impact of FDI inflows on economic growth in Bangladesh in a period of 1989-2017 employing time series analysis techniques that recognize the problem of nonstationary. To ensure the regression is valid the Unit root test and Cointegration test is been used. Findings from empirical results show as FDI inflow, government consumption, population size and joining WTO have a positive impact on economic growth. Also, the exchange rate seems to be less significant in economic growth.
\end{abstract}

Keywords: Bangladesh, Foreign Direct Investment, economic growth, cointegration

\section{Introduction}

A linear way of thinking is that Foreign Direct Investment (FDI) vastly important to economic growth. As general conception dictates that FDI as foreign capital technology injecting into the economy, generates development activity, hence economic growth. As a relationship with the growth per se, FDI became a highly discussed topic in the international development field. Although once a major portion of FDI received by developed countries, FDI appears to be the quickest way to accelerate growth in developing countries (Makki and Somwaru, 2004). The neoclassical growth models, as well as endogenous growth models, provide the groundwork for most of the empirical work on the FDI-growth parity. 
The FDI and growth relationship is still a debatable issue in various factor but a majority of the macroeconomic studies indicates a positive relationship of FDI in economic growth in certain economic state (Lean and Tan, 2011; Alshehry, 2015; Adhikary, 2015). FDI can push economic growth through three major mediums. Firstly, it diversified from wrapped up constraint of domestic investment which also helps to grow domestic savings in a way. Secondly, through FDI, along with the capital, another major factor of production comes in such as technology, method, efficiency, utilization of resources which often absorbed by the host country and formulates long term growth. Thirdly, all these capital, technology and efficient production follow up as increased export, and introduce a new wave of competitiveness in local production. Except for these mediums, there are said to be more factors that come into play, as defined-absorption capacity. Which includes the level of human development, type of trade regimes and trade openness (Umoh et al., 2012; Strauss, 2015).

Even though, the economic indicators show positive signs, the economy of Bangladesh have some problems related to developments. Such as Human Development Index (HDI) is below average, considering other medium economies as well as other south Asian economies. Another issue is the unemployment rate is stood at $4.37 \%$ in 2017 (Source: World Bank) and being steady since 2013 , even though the GDP growth rate are in upward. This growth does not seem to affect much in development and employment. Where FDI inflow should accelerate those in a positive manner.

FDI inflow in Bangladesh in 1994 has started to breakthrough from previous years steady Stream, where in 1995 and 1996 it jumped almost twenty times as 11 million USD to 231 million USD. This rapid growth is a result of a collection of coverage incentives, funding sovereignty has been presented to the FDI buyers consisting of tax vacation for countless years, obligation free facility for importing capital machinery, a hundred percent overseas ownership, a hundred percent income repatriation facility, reinvestment of earnings or dividend as FDI, a couple of visa, work allow to overseas executives, everlasting resident or even citizenship for investing a unique amount, Export Processing Zone (EPZ) facility, and easy hassle-free exit facility. ( Md. Joynal Abdin; 2015). Between 1990-2017, total inflows of FDI were USD 21200.5 million, among which the total inflows of FDI during 2006-2010 was USD 16457.7 million. In 1990, this inflow was USD 3.2 million and in 2008, annual FDI reached USD 1086.31 million. Unfortunately, there was a decline in inflows of FDI in 2010 which was USD 913.32 million (Source: FDI inflow by region and economy, UNCTAD).

This study strives to identify the effect of FDI on economic growth in the perspective of Bangladesh over the period from 1989 to 2017 using time series analysis method that accounts for the problem of nonstationary. In this 
study, it also includes the Unit root test and cointegration approach are applied to make sure that regressions are legitimate.

The rest of this study is sequenced as following- section 2 shows an overview of the literature relates to the impact of FDI on economic growth. Section 3 reports some FDI facts and trends in Bangladesh. Section 4 is providing data description, models and applied test procedures and section 5 discusses the results of the empirical investigation. Finally, section 6 provides a conclusion and possible proposed suggestive policy implications.

\section{Literature Review}

Foreign Direct Investment is the category of international investment that reflects the objective of a resident entity in one economy obtaining a lasting interest in an enterprise resident in another economy (The resident entity is the direct investor and the enterprise is the direct investment enterprise). (IMF, Balance of payment manual)

Neoclassical growth theory emphasizes on capital accumulation and measures to saving it as an important determinant of economic growth. Neoclassical growth model elaborate two-factor production functions with capital and labor as determinants of output. Neoclassical growth theory outlines the three factors (labor, capital, and technology) necessary for a growing economy. Capital and technology are major elements of FDI that an economy receives as in a form of capital.

There are many theoretical studies light the positive impacts of FDI on economic growth, and also other studies proven otherwise. As so, in here the papers related to FDI impacts on economic growth both Bangladesh and foreign countries prospective papers are chosen to refer our study.

\begin{tabular}{|l|l|l|}
\hline \multicolumn{1}{|c|}{ Authors \& years } & \multicolumn{1}{|c|}{ Topics } & \multicolumn{1}{c|}{ Results } \\
\hline $\begin{array}{l}\text { Bahname (2012); } \\
\text { (2012) }\end{array}$ & $\begin{array}{l}\text { The impact of FDI } \\
\text { on economic growth } \\
\text { in South Asia }\end{array}$ & $\begin{array}{l}\text { The results show that FDI, along with other } \\
\text { variables such as human capital, economic } \\
\text { infrastructure, and capital formation have } \\
\text { positive and significant effects on } \\
\text { economic growth. Also, it recommended } \\
\text { more openness of the economies, more } \\
\text { investment in infrastructure and more } \\
\text { political commitment to the fight against } \\
\text { corruption. }\end{array}$ \\
\hline $\begin{array}{l}\text { Carp (2012); Insah } \\
(2013)\end{array}$ & $\begin{array}{l}\text { The impact of the } \\
\text { economic crisis on } \\
\text { the dynamic of } \\
\text { international FDI }\end{array}$ & $\begin{array}{l}\text { Here it analyzes, the significance of the } \\
\text { FDI flow on the host countries economic } \\
\text { growth as an effect of capital flows } \\
\text { exercised in the host country is significant } \\
\text { and main way through the effects are } \\
\text { spread-financial markets, host country } \\
\text { absorptive capacity, human capital and } \\
\text { technological; the elasticity of economic } \\
\text { growth with respect to FDI had a positive }\end{array}$ \\
\hline
\end{tabular}




\begin{tabular}{|c|c|c|}
\hline & & $\begin{array}{l}\text { sign and also significant at the } 1 \% \text { level by } \\
\text { applying the Dynamic Ordinary Least } \\
\text { Squares technique. }\end{array}$ \\
\hline $\begin{array}{l}\text { Kornecki and } \\
\text { Borodulin, } 2011\end{array}$ & $\begin{array}{l}\text { State-Based } \\
\text { Determinants of } \\
\text { Inward FDI Flow in } \\
\text { the US Economy }\end{array}$ & $\begin{array}{l}\text { The research identifies numerous state- } \\
\text { specific determinants of FDI and } \\
\text { investigates the adjustments in their } \\
\text { significance during the research period, } \\
\text { outcome exhibit that amongst the important } \\
\text { determinants, the actual per capita income, } \\
\text { actual per capita expenditure on education, } \\
\text { FDI associated employment, study and } \\
\text { development expenditure, and capital } \\
\text { expenditure are observed to have a } \\
\text { substantial positive affect on FDI inflows. }\end{array}$ \\
\hline $\begin{array}{l}\text { Adamu et al. } \\
\text { (2015) }\end{array}$ & $\begin{array}{l}\text { Remittance, Aid, } \\
\text { Foreign Direct } \\
\text { Investment, } \\
\text { Financial } \\
\text { Development and } \\
\text { Economic Growth in } \\
\text { Nigeria: A Time } \\
\text { Series Analysis }\end{array}$ & $\begin{array}{l}\text { An effective and great relationship between } \\
\text { FDI and actual GDP proxy for economic } \\
\text { development in Nigeria. Therefore, the } \\
\text { existence of this affirmative linkage } \\
\text { necessitates the requirement to proceed } \\
\text { enforcing strategies that will appeal FDI } \\
\text { particularly in the non-oil sectors of } \\
\text { Nigeria. }\end{array}$ \\
\hline $\begin{array}{l}\text { Adhikary, } \\
\text { 2015; } \\
\quad \text { Ghatak and } \\
\text { Halicioglu, 2007; } \\
\text { Lean and Tan, } \\
\text { 2011; Alshehry, } \\
2015\end{array}$ & $\begin{array}{l}\text { Dynamic Effects of } \\
\text { FDI, Trade } \\
\text { Openness, Capital } \\
\text { Formation and } \\
\text { Human Capital on } \\
\text { the Economic } \\
\text { Growth Rate in the } \\
\text { Least Developed } \\
\text { Economies: } \\
\text { Evidence from } \\
\text { Nepal }\end{array}$ & $\begin{array}{l}\text { An empirical study from all of them shows } \\
\text { positive impacts of FDI in economic } \\
\text { growth. }\end{array}$ \\
\hline Mottaleb (2007) & $\begin{array}{l}\text { Determinants of } \\
\text { Foreign Direct } \\
\text { Investment and Its } \\
\text { Impact on Economic } \\
\text { Growth in } \\
\text { Developing } \\
\text { Countries }\end{array}$ & $\begin{array}{l}\text { Panel data from this study reveals, FDI } \\
\text { flows of sixty low-income and lower- } \\
\text { middle-income nations and observed that } \\
\text { FDI has an vital impact on the economic } \\
\text { boom of third world nations by way of } \\
\text { developing a bridge between the hole of } \\
\text { home financial savings and funding and } \\
\text { familiarizing the up to date science and } \\
\text { technology and administration ability from } \\
\text { developed countries. }\end{array}$ \\
\hline $\begin{array}{l}\text { Quader, Syed } \\
\text { Manzur (2009) }\end{array}$ & $\begin{array}{l}\text { Foreign Direct } \\
\text { Investment in } \\
\text { Bangladesh: An } \\
\text { Empirical Analysis } \\
\text { on its Determinants } \\
\text { and Impacts }\end{array}$ & $\begin{array}{l}\text { Here, authors utilized severe bounds } \\
\text { analysis to the records of the a number } \\
\text { catalyst variables of FDI inflows in } \\
\text { Bangladesh. They discovered FDI and } \\
\text { domestic investment have a affirmative } \\
\text { impact on economic growth. }\end{array}$ \\
\hline
\end{tabular}




\begin{tabular}{|c|c|c|}
\hline $\begin{array}{l}\text { Piotr Misztal } \\
(2010)\end{array}$ & $\begin{array}{l}\text { Foreign Direct } \\
\text { Investments as A } \\
\text { Factor for Economic } \\
\text { Growth in Romania, }\end{array}$ & $\begin{array}{l}\text { This study examined the influence of FDI } \\
\text { on the economic growth in Romania in a } \\
\text { period of 2000-2009 using the Vector } \\
\text { Autoregression Model (VAR) and found a } \\
\text { linear relationship between FDI and } \\
\text { economic growth. }\end{array}$ \\
\hline $\begin{array}{l}\text { Shimul et al. } \\
\text { (2009); Geijer } \\
(2008)\end{array}$ & $\begin{array}{l}\text { An examination of } \\
\text { FDI and growth } \\
\text { nexus in Bangladesh }\end{array}$ & $\begin{array}{l}\text { This study attempts to finding the long-run } \\
\text { relationship or cointegration within FDI } \\
\text { and economic growth using time series } \\
\text { data from 1973-2007. The Granger } \\
\text { Causality test shows that FDI and openness } \\
\text { are now not appreciably inflicting the GDP } \\
\text { per capita each in the short and long run . It } \\
\text { suggests applying appropriate measures as } \\
\text { such FDI can be used as a contributing } \\
\text { aspect to the economic improvement in } \\
\text { Bangladesh. Also, comparable outcomes } \\
\text { through the use of a multiple regression } \\
\text { analysis with GDP per capita as a } \\
\text { dependent variable in economy of Mexico. }\end{array}$ \\
\hline $\begin{array}{l}\text { Louzi and Abadi } \\
\text { (2011) }\end{array}$ & $\begin{array}{l}\text { Impact of Foreign } \\
\text { Investment on } \\
\text { Economic Growth }\end{array}$ & $\begin{array}{l}\text { Studied FDI provided growth in Jordan } \\
\text { ranging from } 1990 \text { to } 2009 \text {. The } \\
\text { econometric framework of cointegration } \\
\text { and error correction mechanism is used to } \\
\text { take two-way linkages between involved } \\
\text { variables. The empirical consequences } \\
\text { divulge that FDI inflows do now not have } \\
\text { an effect on economic growth, whilst } \\
\text { domestic investment and liberalization } \\
\text { have superb affects on GDP growth. }\end{array}$ \\
\hline $\begin{array}{l}\text { Mehrara and Musai } \\
\text { (2015) }\end{array}$ & $\begin{array}{l}\text { The Relationship } \\
\text { between Economic } \\
\text { Growth and Human } \\
\text { Capital in } \\
\text { Developing } \\
\text { Countries }\end{array}$ & $\begin{array}{l}\text { Studying the linkage between FDI and } \\
\text { GDP for the Middle East and North Africa } \\
\text { vicinity nations the use of panel unit root } \\
\text { tests and panel cointegration evaluation for } \\
\text { the duration of } 1970-2010 \text {. The result } \\
\text { implies that FDI does not have any } \\
\text { significant effects on GDP in the short-run } \\
\text { and long-run with no growth benefit for the } \\
\text { recipient country. }\end{array}$ \\
\hline $\begin{array}{l}\text { Borensztein et } \\
\text { al. (1998) }\end{array}$ & $\begin{array}{l}\text { How does foreign } \\
\text { direct investment } \\
\text { affect economic } \\
\text { growth? }\end{array}$ & $\begin{array}{l}\text { Calculating FDI flows from industrial } \\
\text { countries to } 69 \text { developing countries over } \\
\text { the period 1970-1989. It shows FDI is an } \\
\text { important way of transfering technology, } \\
\text { contributing exceptionally extra to growth } \\
\text { than domestic investment. But also, FDI } \\
\text { fuels economic growth only if the host } \\
\text { country can absorb the technology } \\
\text { properly. }\end{array}$ \\
\hline $\begin{array}{l}\text { Omran and Bolbol } \\
(2003)\end{array}$ & $\begin{array}{l}\text { Foreign Direct } \\
\text { Investment, }\end{array}$ & $\begin{array}{l}\text { FDI has a positive influence on economic } \\
\text { growth if there is a certain level of }\end{array}$ \\
\hline
\end{tabular}




\begin{tabular}{|l|l|l|}
\hline & $\begin{array}{l}\text { Financial } \\
\text { Development, and } \\
\text { Economic Growth: } \\
\text { Evidence from the } \\
\text { Arab Countries }\end{array}$ & $\begin{array}{l}\text { development that exists in the host country } \\
\text { otherwise it has a negative impact. }\end{array}$ \\
\hline $\begin{array}{l}\text { Jyun-Yi and Chih- } \\
\text { Chiang (2008) }\end{array}$ & $\begin{array}{l}\text { Does foreign direct } \\
\text { investment promote } \\
\text { economic growth? } \\
\text { Evidence from a } \\
\text { threshold regression } \\
\text { analysis }\end{array}$ & $\begin{array}{l}\text { Dataset of 62 countries covering the period } \\
\text { from 1975 to 2000, shows FDI impact on } \\
\text { economic growth dependent on different } \\
\text { absorption capacities and they found that } \\
\text { initial GDP and human capital are an } \\
\text { important factor in FDI. }\end{array}$ \\
\hline $\begin{array}{l}\text { Mohammed Ershad } \\
\text { Hussain and } \\
\text { Mahfuzul Haque } \\
\text { (2016) }\end{array}$ & $\begin{array}{l}\text { Foreign Direct } \\
\text { Investment, Trade, } \\
\text { and Economic } \\
\text { Growth: An } \\
\text { Empirical Analysis } \\
\text { of Bangladesh }\end{array}$ & $\begin{array}{l}\text { With VECM, this study founds trade and } \\
\text { foreign investment variables have a large } \\
\text { influence on the growth percentage of GDP } \\
\text { per capita. As FDI and trade are two } \\
\text { essential instruments of economic boom in } \\
\text { Bangladesh. }\end{array}$ \\
\hline
\end{tabular}

\section{Overview of economic growth and FDI in Bangladesh}

Bangladesh is a new frontier of development in the Asia region. Policies have been taken by government and incentive plans in the 1990s to encourage FDI, has been transformed Bangladesh from per capita income $\$ 170$ USD into a lower middle-income country within a couple of decades with per capita of \$ 1,564 USD (World Bank, 2017). The Poverty headcount ratio at national poverty line has fallen from 56\% in 1990 to $24 \%$ in 2016, including most of the welfare improved significantly. Bangladesh has accomplished eight of its ten Millennium Development Goal targets and is well on the way to achieve the rest two.

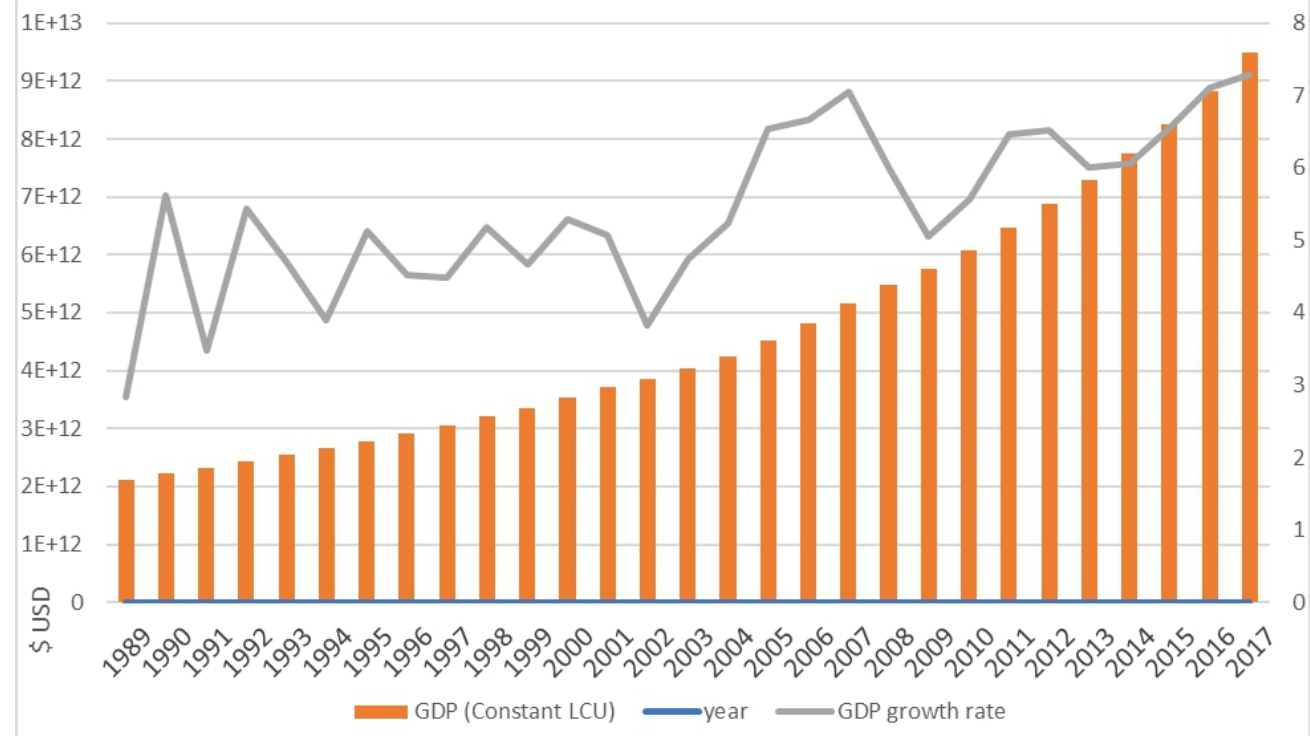

Figure 1: GDP and GDP growth rate of Bangladesh, 1989-2017; Source: World Bank, 2018 
Given in figure 1, we can see that Bangladesh accomplished a rapid growth in 1995-1996 as 5.12\% compared to $3.8 \%$ in 1994 . This upward trend dropped to $3.8 \%$ due to political turmoil, in 2002 and we can see the relative drop down to $5.04 \%$ compared to previous year $7 \%$ due to the same reason. However, we can see steady growth from 1994 till 2017, as it stands highest $7.05 \%$ before the worldwide financial market collapse in 2008. But in the last decade or so the growth rate holding steady as $7.2 \%$ in 2017 , even though global financial and economic downturn.

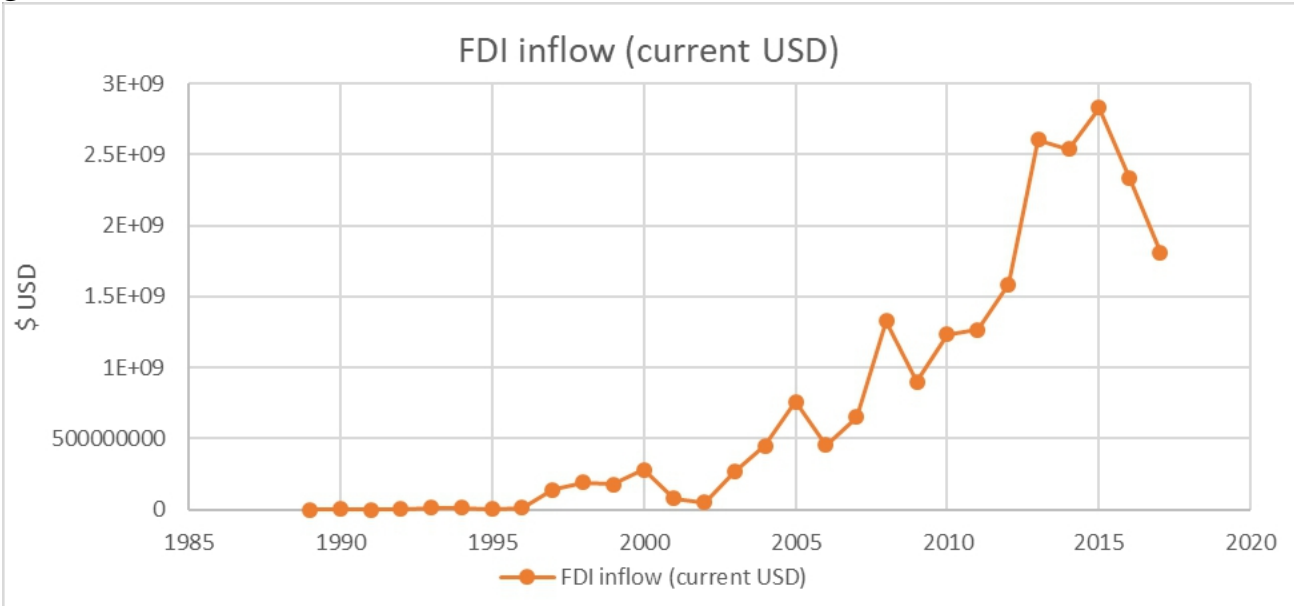

Figure 2: FDI inflows into Bangladesh, 1989-2017, Source: World Bank, 2018

FDI inflows increased noticeably since the policy changes to encourage FDI as well as incentive programs respectively in 1990 and 1995. Also, another possible reason is lifted up restrictions on capital and profit tunneling to origin country and opened up almost all industrial sectors to foreign investors coming solo or joint partnership with local entities, during the 1989 period can also be considered as a contributor. In 1989 the authorities set up Board of Investment (BOI). The foremost goal of which is aimed at tunneling and facilitating investment from overseas (Mondal 2003). This results from an influx of increased FDI growth after 1995, although in the 2001-2002 period there is decline performance due to political turmoil, which can be seen in the 2009 period too, where international financial market collapse could be a potential reason. As in 2015 is seen as the highest amount of FDI received of $\$ 2.83$ billion USD. The huge influx can be noticed from the year 2002, \$52 million USD to almost \$2 billion USD in growth amount. 
Table 1: FDI inflow into Bangladesh by sector, 1996-2017

\begin{tabular}{|l|l|} 
Sectors & Total (USD million) \\
\hline Manufacturing & 7475.4 \\
Transport, storage \& communication & 4544.69 \\
\hline $\begin{array}{l}\text { Power, Gas \& Petroleum } \\
\text { Trade \& commerce }\end{array}$ & 4039.87 \\
\hline $\begin{array}{l}\text { Service } \\
\text { Agriculture \& Fishing }\end{array}$ & 3858.07 \\
Other sectors & 679.78 \\
Construction & 312.42 \\
\hline
\end{tabular}

Source: Bangladesh Bank survey, 2017

We can see in Table 1, most of the FDI inflows in Bangladesh are in Manufacturing, amounting to $\$ 7.47$ billion USD. While transport, storage \& communication or as physical infrastructure Flow is $\$ 4.5$ billion USD along with energy sector over $\$ 4$ billion USD. This data emphasizes that the potentiality of the manufacturing industry in Bangladesh. Also, for long term development, the cruciality of infrastructure and energy sector is been recognized. While the data also reveals, the rapid growth shift along with the FDI and following FDI sectors from the last decade, trending from 2007 and onwards. However, the last couple of years, FDI inflow moving to increased export-oriented and labor-intensive industries, as the trade and commerce sector climbing up. On the other hand, service and agricultural sector is being significant.

Table 2: Top 5 countries FDI inflow in Bangladesh, 1996-2017

\begin{tabular}{l|l|} 
Country of origin & FDI infl \\
\hline U. $K$ & 3097.63 \\
\hline U.S. A & 2352.08 \\
\hline Singapore & 1923.2 \\
\hline South Korea & 1610.16 \\
\hline Netherlands & 1264.45 \\
\hline
\end{tabular}

Source: Bangladesh Bank survey, 2017

In the case of FDI sources, the majority portion of the FDI comes from the European and western sources. Table 2, visualizing the top 5 countries contributing to Bangladesh in a period of 1996-2017 as a manner of inward FDI. Among these countries, the United Kingdom is formulated the largest portion of FDI inflows in over \$3 billion USD. Followed by, United States and Singapore formulating $\$ 2.4$ billion and $\$ 1.9$ billion USD respectively. Although South Korea, Geographic proximity between aisan countries results higher FDI flow doesn't seem to apply here, as we can see the major portion of inward FDI coming from European countries (Redwanur Rahman, Saleh Shahriar, Sokvibol Kea, 2019). Also, noticeably, this inward flow mainly start 
in late 2002. It is known that multinational corporations (MNCs) prefer developing countries as an export production location, often with the intention to reduce manufacturing costs as by utilizing given production factors. As being the world's 8th largest population (UN), Bangladesh inherits one of the largest labor resourced countries even among other Asian countries. As a result, it's a comparative advantage in labor-intensive production, intensifying the competitiveness to attract MNCs.

\section{Methodology and Data \\ Model specification}

Following the theoretical models of the neoclassical, endogenous growth model and various empirical analysis models as like Borensztein et al. (1998), Hoang et al. (2010), Adhikary (2015) and econometric model sourced from production function framework where FDI has been taken as factor of input, along with Domestic investment, Government consumption, Exchange rate, Population size and, WTO. Following model is been used in this study-

$$
\begin{aligned}
& \operatorname{Ln}(G G R t)=\beta 0+\beta 1 \operatorname{Ln}(F D I t)+\beta 2 \operatorname{Ln}(D I t)+\beta 3 \operatorname{Ln}(G C t)+\beta 4 \operatorname{Ln}(E X R t)+ \\
& \beta 5 \operatorname{Ln}(P S t)+\beta 6(W T O t)+\mu t
\end{aligned}
$$

Here, $\boldsymbol{\beta} 1, \boldsymbol{\beta 2}, \ldots . . ., \boldsymbol{\beta} 10$ are coefficients of elasticities; Ln used to describe natural logarithm of variables; $\boldsymbol{\mu t}$ is the error term,

GGR $=$ GDP growth rate

FDI $=$ Foreign Direct Investment inflows in Bangladesh

$\mathrm{DI}=$ Domestic Investment

$\mathrm{GC}=$ Government consumption (as a percentage of GDP)

$\mathrm{EXR}=$ Exchange rate

$\mathrm{PS}=$ Population size

$\mathrm{WTO}=$ World Trade organization (Dummy variable)

The use of log-linear specification is to determine the coefficient of variables, which has many reasons. Firstly, the link between different variables is nonlinear. Secondly, the value of coefficients of the log model can be translated as of percentage or elasticity other than a unit. Among these variables, Government consumption and exchange rate thought to posses a negative relationship with Bangladesh's economic growth and other variables are hoped to inherit a positive influence on economic growth.

To estimate time-series data, unit root test is used to verify the stationary state of the variables (Johnston and Ramirez, 2015). Then, the stationary features of the individual data has been founded, Straight groupings 
of the unified sequence are examined for cointegration. performing cointegrating test, here Johansen cointegration methodology is been applied.

\section{Data}

This study based on an annual time series data cluster with a time period of 1989 to 2013. 1989 to 2017 was selected because to get a better sample size, and 1996 to 2017 because Bangladesh joined WTO in 1995 and in the year 1995 Bangladesh was opened up. The data are collected from the World Bank, World Bank Development Indicators, International Monetary Fund (IMF) and Bangladesh Bank survey.

\section{Empirical results} Unit root test

Time series data can be defined by the test of non-stationary which results in artificial value. To examine for stationary of individual variable, the Augmented Dickey-Fuller (ADF) unit root test is used to the variables in level and in $1^{\text {st }}$ difference. The ADF test results for the variables related to the analysis are shown in Table 3. The findings suggest that the null hypothesis existence of unit root or non-stationary has been denied for all first difference variables specified. This shows that all variables present built-in order one. As it also defines that the series are non-stationary in level but stationary in first difference, implying there is a certainty of having a cointegrating vector of which coefficient can immediately be explained as the long-term equilibrium.

Table 3: Augmented Dickey-Fuller Unit root test

\begin{tabular}{|l|l|l|l|l|}
\hline Series & level & First Difference & \\
& Without Trend & With Trend & Without Trend & With Trend \\
\hline Ln GGR & 0.1237 & 0.0008 & 0.0000 & 0.0000 \\
\hline Ln FDI & 0.0682 & 0.9773 & 0.0001 & 0.0002 \\
\hline Ln DI & 0.9960 & 0.5268 & 0.0044 & 0.0177 \\
\hline Ln GC & 1.0000 & 0.7845 & 0.2289 & 0.1881 \\
\hline Ln EXR & 0.9899 & 0.0261 & 0.0026 & 0.0117 \\
\hline Ln PS & 0.0122 & 0.6341 & 0.4327 & 0.0023 \\
\hline
\end{tabular}

Source: Author's calculation

\section{Cointegration test}

Since variables exhibit integrated order one, the next step is to use Johannsen's test to investigate the presence of long-term relationships within the variables. The test consists of two configurations, the Johansen trace test, and the maximum eigenvalue test. Table 4 shows the number of cointegrating vectors. 
Table 4: Johansen Cointegration Test results

Hypothesized

Trace

0.05

No. of $\mathrm{CE}(\mathrm{s})$

Eigenvalue

Statistic

Critical Value

Prob.**

\begin{tabular}{ccccc}
\hline \hline None $*$ & 0.944884 & 229.9600 & 125.6154 & 0.0000 \\
At most 1* & 0.918869 & 154.6036 & 95.75366 & 0.0000 \\
At most 2* & 0.785605 & 89.29956 & 69.81889 & 0.0007 \\
At most 3* & 0.612237 & 49.26129 & 47.85613 & 0.0367 \\
At most 4 & 0.460014 & 24.62992 & 29.79707 & 0.1751 \\
At most 5 & 0.171967 & 8.608383 & 15.49471 & 0.4028 \\
At most 6 & 0.132717
\end{tabular}

Source: Author's calculation

Trace test indicates 4 cointegrating eqn(s) at the 0.05 level

$*$ denotes rejection of the hypothesis at the 0.05 level

**MacKinnon-Haug-Michelis (1999) p-values

Table 4 shows that the trace test and maximum eigenvalue test there is the presence of 4 cointegrating vectors at $1 \%$ level and $3 \%$ level of significance. These results confirm a long-run relation within GGR, FDI, domestic investment, government consumption, Exchange rate, Population size and WTO in Bangladesh.

Table 5: Empirical results

\begin{tabular}{ccccc} 
Variable & Coefficient & Std. Error & t-Statistic & Prob. \\
\hline \hline C & 94.65281 & 38.74132 & 2.443201 & 0.0235 \\
LN_FDI & 0.070145 & 0.034832 & 2.013778 & 0.0570 \\
LN_DI & -0.516101 & 0.284366 & -1.814919 & 0.0838 \\
LN_GC & 1.313620 & 0.531141 & 2.473204 & 0.0220 \\
LN_PS & -6.413377 & 2.309258 & -2.777246 & 0.0113 \\
LN_EXR & 0.886252 & 0.565331 & 1.567668 & 0.1319 \\
WTO & 0.385513 & 0.174060 & 2.214828 & 0.0380
\end{tabular}

Source: Author's calculation

The results from Table 5 shows there is a long-term relationship within the variables. The coefficient of FDI inflows is positive and statistically significant at 5\% level, explaining FDI has a positive effect on Bangladesh's economic growth. Also, it shows that $1 \%$ rise in inward FDI usually increases $0.07 \%$ of GDP growth rate. These results agree with FDI backed growth hypothesis of Borensztein et al. (1998), Lean and Tan (2011), Insah (2013) and Iqbal and Abbas (2015). FDI is an important source of many industries in 
elements of technology, value-added products, technical services. It also balances foreign exchange and the national balance of payments.

Domestic investment is being positive and statistically significant for economic growth at $8 \%$ level of significance. Although, the coefficient of elasticity shows the positive impact of FDI in economic growth, and long-term impact in economic growth. Also, (Redwanur Rahman, Saleh Shahriar, Sokvibol Kea, 2019) study shows that the prime sector of export $89 \%$ of textile and where $95 \%$ investment in the textile industry comes from domestic investment. The policy to encourage domestic investment is been incentivized along with the foreign investors to give same level of facilities. To be in per with foreign entities domestic private sector is also being competitive.

Government consumption has less positive and statistically significant for economic growth at $2 \%$ level of significance, but in overall perspective, is considered to be as less significant. It is due to accelerate the FDI in Bangladesh.

Population size is $1 \%$ level of significance, as a proxy of human capital. It shows a large population positively impact as well as long term on the economic growth of Bangladesh. A higher level of human capital tends to push the growth of aggregate output, prevent the decrease of marginal product, thereby promoting economic growth (Adhikary, 2015). Olatunji and Shahid (2015) also suggest that a greater level of education in the workforce can boost economic growth.

The exchange rate is $13 \%$ level, which in translation can be said that is not significant. Although the effect on economic growth is varied from short term to long term. But as a measure of GDP growth rate, it is not significant but can be in GDP output in a given period.

WTO is a dummy variable here, and it is $3 \%$ level of significance. Joining in WTO enhances economic growth as we can see from the data where influx in GDP growth as from 1995 to onward. We also find evidence from a study (Redwanur Rahman, Saleh Shahriar, Sokvibol Kea, 2019), where WTO joining has increase economic growth from the year 1995.

\section{Diagnostic test}

To prove the credibility of our determined model, several diagnostic tests were used (Salim et al., 2015). Table 6 shows that the model passes the diagnostic tests including the Breusch-Godfrey Serial Correlation LM test, Jacque-Berra normality test, CUSUM stability test, autoregressive conditional heteroscedasticity (ARCH) test, and Ramsey RESET test. All calculated statistics were insignificant, indicating that there is no problem of serial correlation, heteroscedasticity, non-normality, and functional form misspecification in the model. 
Table 6: Diagnostic test

\begin{tabular}{lll}
\hline Test & F-statistics & p-value \\
\hline Breusch-Godfrey LM test & 0.011950 & 0.9881 \\
Jacque-Berra test & 1.491390 & 0.474405 \\
ARCH test & 0.848133 & 0.3659 \\
Ramsey RESET Test & 1.302760 & 0.2672 \\
\hline
\end{tabular}

Source: Author's calculation

\section{CUSUM Test}

Figure 3: Recursive estimation test CUSUM test

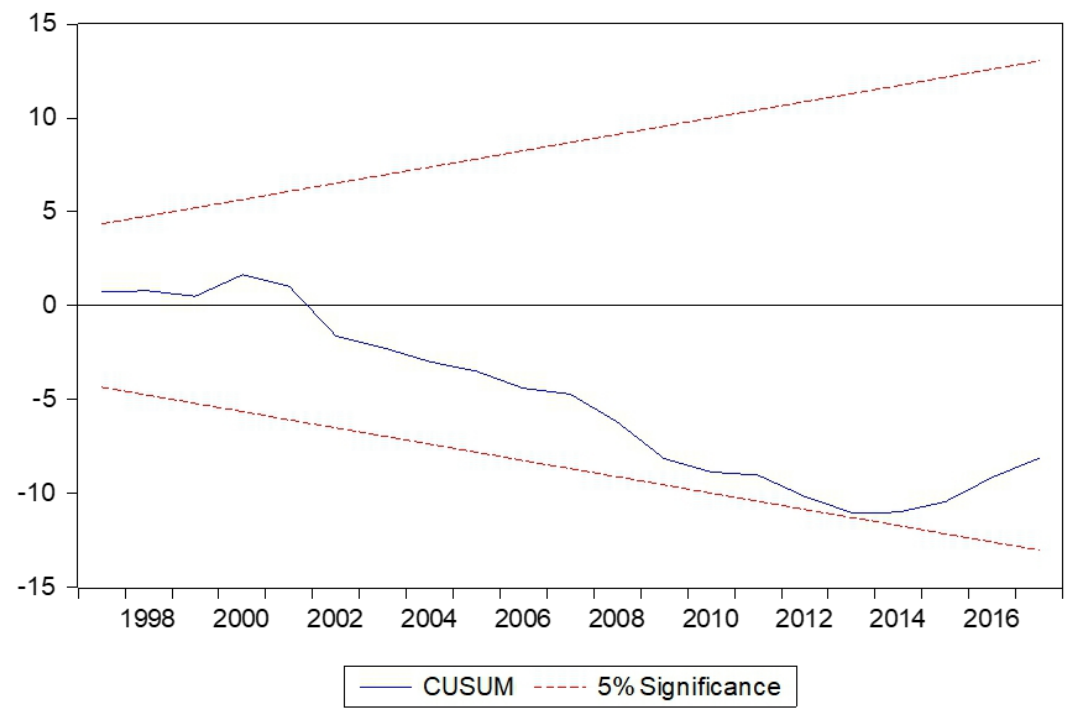

Source: Author's calculation

The CUSUM test shows that our model is stable and 5\% level significant and the CUSUM curve intersects in levels.

\section{Conclusion}

FDI is one of the effective ways to transfer wealth and technology in either developed or developing countries. Multinational corporations (MNCs) are the major bearer of FDI and are constantly looking to tap new markets or low-cost production locations for monetary and strategic incentives, also accelerate socio-economic enrichment (Idoko et al., 2015). This study analyses the impact of incoming FDI on economic growth in Bangladesh with a time frame of 1989-2017 using the time series method. The empirical calculation visualizes that FDI, government consumption, Domestic investment, population size and joining WTO has a positive influence on economic growth. But also, these are significant in the long term. In addition, 
the result also reveals that the exchange rate has a negative influence on economic growth, where it is not significant.

It can be recommended by this study that the Bangladesh government can improve in a few factors that can further assist an ideal environment for FDI destination. Such as, improving governing regulation of business activities, improve ease of doing business, increase the level of security, cutting down governmental bureaucracy, increase foreign trade and trading activities or incentivized in a manner to attract FDI.

There are few limitations of this study. At first, there are other variables that can change the value such as, consumer price index (CPI) by which the outcome can be different. In the case of CPI, there was insufficient data was available for the time-series method, hence excluded. Secondly, there is no proper and complete data were available for Domestic Investment, which was calculated by subtracting domestic investment from GDP. Thirdly, there was no information found on the data set of public and private investment, which could improve the research, also government consumption has to done by the second difference since data unavailability. on the other hand, VAR and autoregression have been used but then the model becomes insignificant.

As our economic boost is primarily by Foreign direct investment and domestic investment. Where our neighboring country's dependency on FDI is higher and as for Bangladesh is less dependent on FDI and by applying the same contribution of FDI as other Asian countries did, we could see a huge influx in economic growth in Bangladesh. Future researchers can find ways to how to increase FDI and what sort of policies or initiatives can increase the FDI inflow.

\section{References:}

1. Abdullahi, Y. Z, Aliero, H. M., \& Yusuf, M. A. (2012). Does FDI Cause Economic Growth? Evidence from Selected Countries in Africa and Asia. African Journal of Social Sciences, 2(4), 114-124.

2. Adamu, J., Idi, A., \& Hajara, B. (2015). FDI and Economic Growth Nexus: Empirical Evidence from Nigeria (1970-2012). Journal of Economics and Sustainable Development, 6(6), 87-89.

3. Adhikary, B. K. (2015). Dynamic Effects of FDI, Trade Openness, Capital Formation and Human Capital on the Economic Growth Rate in the Least Developed Economies: Evidence from Nepal. International Journal of Trade, Economics and Finance, 6(1), 1-7.

4. Alshehry, A. S. (2015). Foreign Direct Investments and Economic Growth in Saudi Arabia: A Cointegration Analysis. Developing Country Studies, 5(6), 69-76. 
5. Bahname, M. (2012). Foreign Direct Investment and Economic Growth: Evidence from Southern Asia. Atlantic Review of Economics, 2(2), 34-48.

6. Bangladesh Bank, Survey 2017, page 24-40.

7. Borensztein, E., De Gregorio, J., \& Lee, J-W. (1998). How does Foreign Direct Investment Affect Economic Growth. Journal of International Economics, 45(1), 115-135.

8. Caner, M., \& Hansen, B. E. (2004). Instrumental Variable Estimation of a Threshold Model. Economic Theory, 20(5), 813-843.

9. Carkovic, M., \& Levine, R. (2002). Does Foreign Direct Investment Accelerate Economic Growth. In Moran, T.H, Graham, E. M. and Blomstrom, M. (Eds.), Does Foreign Investment Promote Development, (pp. 195-220). Washington: Institute for International Economics.

10. Carp, L. (2012). Analysis of the Relationship Between FDI and Economic Growth - Literature Review Study. The USV Annals of Economics and Public Administration, 12(1), 154-160.

11. Geijer, K. (2008). Foreign Direct Investment in Mexico: Possible Effects on the Economic Growth (Master's thesis). Department of Economics, Uppsala University.

12. General Statistics Office. (2014). Statistical Yearbook of Vietnam 2014. Vietnam: Statistical Publishing House. Ghatak, A., \& Halicioglu, F. (2007). Foreign Direct Investment and Economic Growth: Some Evidence from Across the World. Global Business and Economics Review, 9(4), 381-394.

13. Hoang, T. T., Wiboonchutikula, P., \& Tubtimtong, B. (2010). Does Foreign Direct Investment Promote Economic Growth in Vietnam. ASEAN Economic Bulletin, 27(3), 295-311.

14. Idoko, C. U., Idachaba, D., \& Emmanuel, A. (2015). The Effects of Foreign Direct Investment on Sustainable Development in Nigeria. European Journal of Business and Management, 7(6), 82-86.

15. Insah, B. (2013). Foreign Direct Investment Inflows and Economic Growth in Ghana. International Journal of Economic Practices and Theories, 3(2), 115-121.

16. Iqbal, Z., \& Abbas, K. (2015). An Econometric Analysis of Foreign Direct Investment and Economic Growth of Pakistan. Developing Country Studies, 5(11), 16-25.

17. Johnston, K. A., \& Ramirez, M. D. (2015). Foreign Direct Investment and Economic Growth in Cote D'Ivoire: A Time Series Analysis. Business and Economic Research, 5(2), 35-47. 
18. Jyun-Yi, W., \& Chih-Chiang, H. (2008). Does Foreign Direct Investment Promote Economic Growth? Evidence from a Threshold Regression Analysis. Economic Bulletin, 15(12), 1- 10.

19. Katerina, L., John, P., \& Athanasios, V. (2004). Foreign Direct Investment and Economic Growth in Transition Economies. South Eastern Europe Journal of Economics, 2(1), 97-110.

20. Ketels, C., Nguyen, D. C., Nguyen, T. T. A., \& Do, H. H. (2010). Vietnam Competitiveness Report 2010. Central Institute for Economic Management, MPI \& Asia Competitiveness Institute, Lee Kuan Yew School of Public Policy, National University of Singapore.

21. Kokko, A., \& Tran, T. T. (2014). Foreign Direct Investment and the Survival of Domestic Private Firms in Viet Nam. Asian Development Review, 31(1), 53-91.

22. Kornecki, L., \& Borodulin, V. (2011). FDI Contributes to Output Growth in the U.S. Economy. Journal of US- China Public Administration, 8(1), 104-109.

23. Lean, H. H., \& Tan, B. W. (2011). Linkages between Foreign Direct Investment, Domestic Investment and Economic Growth in Malaysia. Journal of Economic Cooperation and Development, 32(4), 75-96.

24. Louzi, B. M., \& Abadi, A. (2011). The Impact of Foreign Direct Investment on Economic Growth in Jordan. International Journal of Research and Reviews in Applied Sciences, 8(2), 253-258.

25. Makki, S. S., \& Somwaru, A. (2004). Impact of Foreign Direct Investment and Trade on Economic Growth: Evidence from Developing Countries. American Journal of Agricultural Economics, 86(3), 795-801.

26. Mehrara, M., \& Musai, M. (2015). The Effect of FDI on Economic Growth in MENA Region. International Journal of Applied Economic Studies, 3(1), 11-16.

27. Mohammed Hussain-Mahfuzul Haque (2016). Foreign Direct Investment, Trade, and Economic Growth: An Empirical Analysis of Bangladesh- Economies, issue-5, vol-4, page-7

28. Nam Hoai Trinh, Quyanh Anh Mai Nguyen (2015), The Impact of Foreign Direct Investment on Economic Growth: Evidence from Vietnam; Developing country studies

29. Nguyen, H. B. (2003). Foreign Capital and Economic Growth: A Comparative Study of Malaysia, Thailand and Vietnam (Doctoral Dissertation). Graduate School of Economics, Osaka Sangyo University.

30. Nguyen, N. A., \& Nguyen, T. (2007). Foreign Direct Investment in Vietnam: An Overview and Analysis the Determinants of Spatial Distribution Across Provinces. MPRA Working Paper, No. 1921. 
31. Nguyen, P. L. (2006). Foreign Direct Investment in Vietnam: Impact on Economic Growth and Domestic Investment. Economics Working Paper, University of South Australia.

32. Ohno, K., \& Le, H. T. (2014). Key Issues for FDI Policy Reformulation in Vietnam. Journal of Economics and Development, 16(3), 5-31.

33. Olatunji, L., \& Shahid, M. S. (2015). FDI and Economic Growth in Nigeria: A Co-integration Analysis. Business and Economic Research, 5(1), 243-261.

34. Omran, M., \& Bolbol, A. (2003). Foreign Direct Investment, Financial Development, and Economic Growth: Evidence from the Arab Countries. Review of Middle East Economics and Finance, 1(3), 231249.

35. Rahman, R., Shahriar, S., \& Kea, S. (2019). Determinants of Exports: A Gravity Model Analysis of the Bangladeshi Textile and Clothing Industries.FIIB Business Review, 8(3), 229-244. https://doi.org/10.1177/2319714519872643

36. Salim, N. J., Mustaffa, R., \& Hanafiah, N. J. A. (2015). FDI and Economic Growth Linkages in Malaysia.Mediterranean Journal of Social Sciences, 6(4), 652-657.

37. Shahrivar, R. B., \& Jajri, I. B. (2012). How Does Inflow of FDI Affect Economic Growth in East Asia. International Economic Studies, 40(1), 15-25.

38. Shimul, S. N., Abdullah, S. M., \& Siddiqua, S. (2009).An Examination of FDI and Growth Nexus in Bangladesh: Engle Granger and Bound Testing Cointegration Approach. BRAC University Journal, 6(1), 6976.

39. Strauss, L. (2015). FDI Inflows and Economic Growth in South Africa from 1994 to 2013 (Master's thesis). School of Economics and Management, Lund University.

40. Umoh, O. J., Jacob, A. O., \& Chuku, C. A. (2012). Foreign Direct Investment and Economic Growth in Nigeria: An Analysis of the Endogenous Effects. Current Research Journal of Economic Theory, 4(3), 53-66.

41. Wijeweera, A., Villano, R., \& Dollery, B. (2010). Economic Growth and FDI Inflows: A Stochastic Frontier Analysis. The Journal of Developing Areas, 43(2), 143-158.

42. World Bank. (2017). World Development Indicators 2017. World Bank Publications.

43. Yaseen, H. (2014). The Impact of Foreign Direct Investment FDI on Economic Growth of Jordan. European Journal of Business and Management, 6(39), 121-128. 
44. Zadeh, H. A., \& Madani, Y. (2012). Financial Market Development, FDI and Economic Growth in Iran. Journal of Basic and Applied Scientific Research, 2(1), 228-230. 